\title{
Extremely Low Frequency Electromagnetic Field (ELF-EMF) and childhood leukemia (CL) near transmission lines: a review
}

\author{
P. A. Kokate ${ }^{2 *}$, A. K. Mishra ${ }^{1}$, S. K. Lokhande ${ }^{2}$, G. L. Bodhe ${ }^{2}$ \\ ${ }^{1}$ School of Energy \& Environmental Studies, Devi Ahilya Vishwavidyalaya, Indore, 452001, Madhya Pradesh. \\ India. \\ ${ }^{2}$ Analytical Instrumentation Division, National Environmental Engineering Research Institute (NEERI), Nagpur, \\ 440020, Maharashtra, India. \\ *corresponding author, Email: pa_kokate@neeri.res.in
}

\begin{abstract}
Children of the 21 st century are continually exposing to multiple sources of electromagnetic field (EMF). By past few years, low frequency between 50 to 60 $\mathrm{Hz}$ shows consistent evidences of childhood leukemia(CL) and other epidemiological disorders in European and other developed countries .This article presents a systematic review of most cited studies from developed countries those shed light on the potential relation between childhood leukemia and extremely low frequency electromagnetic field (ELFEMF). All the findings of articles critically segregated as per human science scale like number of samples, exposure duration, frequency range, distance from the radiation sources, and location during measurement of magnetic field density near power lines. Some other significant effects of change in protein expression, neurological studies are also discussed in this work. The literatures of major studies since last two decade is divided according to pooled analysis /meta-analysis, residential zone assessment and case-control studies.
\end{abstract}

It is very difficult to conclude common conclusion from all the results due non-homogeneous case control studies and complex exposure statistics; however is an attempt to fill the gap between electromagnetic field assessment and medical exposure analysis. The majority of findings were weakly associated with ELF-EMF and childhood leukemia if magnetic field exposure level $\geq 0.3 / 0.4$ $\mu \mathrm{T}$. Most of the scientific outcomes show ambiguous support for association with children's health residing near power transmission line. Wide discrepancy between short-term exposure and long-term exposure was observed during statistical analysis. However, the long-term exposure effects may be repeated in the highly populated and developing countries like India. Hence, assessment, review and analysis of ELF-EMF and its co relation with carcinogenic diseases is highly essential to protect young generation from this unknown future threat.
Keywords: extremely low frequency EMF, childhood leukemia, acute lymphoblastic leukemia.

\section{Introduction}

Modern society is continuously exposing to the different degree of electromagnetic fields (EMF). Initially, the sunlight, lightning and cosmic rays were the only sources of natural EMF. We have added an enormous amount of artificial electric field (E-field) and magnetic field (H-field) in ambient environment due to high power transmission lines (HPTL), distribution line, electric gadgets, AM/FM/mobile towers, cell phone etc. $[1,2]$. By the past few years, consistent epidemiological evidence demonstrates the risk of childhood leukemia. Hence, IARC classified the ELF in $2 \mathrm{~B}$ category i.e. "possibly carcinogenic". $[3,4]$. The residents living in the proximity of transmission line are feeling similar situation like faradays cage where they always exposed to ELF$\mathrm{EMF}$ at 50 to $60 \mathrm{~Hz}$. Hence, there is dire need to monitor ELF as per the common standard guidelines and identify future threat for young generation.

Childhood Leukemia occurred due to chromosomal alteration and mutations in the regular cell growth. This type of childhood cancer creates non-mature growth of blood cell without control in reproducibility of healthy cells. Most series of accumulation turn genetic changes over a long time. A wide variety of exposure factors are involved in the development of this disease. In this critical review, initial part introduces ELF and its standard assessment methodology. Next part describes the studies related to childhood leukemia and divided in relation to pooled analysis / meta-analysis, residential zone assessment and case control studies. Final part highlights some physical ignored parameters that can be analyzed without exposure statistic knowledge. 


\section{ELF-EMF and Methodology}

Electromagnetic field is a combination of electric and magnetic field oscillate perpendicular to each other in the direction of energy propagation. The ITU (International Telecommunication Union) has categorized electromagnetic spectrum depending upon their frequencies as extremely low frequency (ELF-EMF), low frequency (LF-EMF) and high frequency (HF-EMF) [5]. ELF-EMF are accessible in the range of $1 \mathrm{~Hz}$ to $100 \mathrm{KHz}$, its natural sources are tropical thunderstorm and geomagnetic activities, while artificial sources are high power lines, power grids, and electronic gadgets, electrical cables etc. [6, 7, 8]. The Institute of Electrical and Electronics Engineers (IEEE) released standard guidelines for ELF-EMF and included methodology for monitoring whole frequency of radiations. Further International Commission on Non-Ionizing Radiation Protection (ICNIRP) reported their modified guidelines for overload high-voltage power lines [9, 10]. Also World Health Organization have endorsed for longterm exposure studies on ELF using ICNIRP guidelines (WHO: www.who.int/emf) [11]. Hence, both standard guidelines are adapted during scrutiny of the work.

This literature research composed in the first quarter of 2015 in reference of web of science (ISI) knowledge and google scholar database. More than 50 Publications were selected that include a conclusive interpretation of case-control studies, meta-analysis, pooled analysis with EMF and its biological relevance. However, the complete review of biological and health effects was beyond the scope of this paper. Complex exposure statistic is very difficult to understand for electrical engineering community. Hence the scientifically understandable, non-biological, neglected physical parameters were selected to link this study. The electromagnetic field evaluation criteria such as exposure dose, assessment duration, place of experiment, distance from source and frequency range was focused during the selection of articles.

\section{Relation between ELF-EMF and childhood leukemia}

First time reported an occurrence of childhood leukemia in clustering methodology [13]. In 1979, [14] carried out an epidemiological study to understand exposure dose on houses using wire code configuration. Numerous studies and opinions were documented in the USA and European countries to identify the relationship between ELF-EMF and chronic diseases. These studies were critically assessed in the area where human beings more prone to expose of an electrostatic field. [15], conducted impact assessment of magnetic field on 638 children's bedroom for 24 hours, near the power lines. They found direct proportionality equation between the strength of magnetic field and the risk of childhood leukemia. According to [16] the special attention is required for children than adults because they spare more time in the house. Consequent effects were more vulnerable on minors compared to adults. It was very difficult to conduct individual research to identify biological effects of ELF. Hence, similar secondary associative studies in same era had been conducted. These studies were more complex and heterogeneous case control studies. These can be categorized into pooled analysis, residential zone assessment and case control studies.

\section{Pooled and meta-analysis}

[17], approves the presence of an association between $\mathrm{H}$-fields and leukemia among people whose residence surrounded by high voltage transmission electric lines. When the OR(odd ratio) increased with exposure of 4 to $10 \mathrm{mG}$, then risk also increased with distance from $25 \mathrm{~m}$ to $50 \mathrm{~m}$ from transmission lines. Their conclusions were collectively applicable for adults as well as for children. [18], scrutinized the 15 studies from original individual data and pointed out that the children exposed $>0.3 \mu \mathrm{T}$ has a higher risk of leukemia. Most powerful attempt in pooled analysis by [19] based on individual records from nine studies, involves 3203 case and 10338 controls. Given finding, suggested that the children with exposure levels below $0.4 \mu \mathrm{T}$ had no increased risk while the children with exposures above $0.4 \mu \mathrm{T}$ could be relative risk of 2.0. A risk declining over time is unlikely to arise from any physical effect of the power lines and is more likely to be the result of changing population characteristics among those living near power lines. [20], in the cumulative metaanalysis of 19 studies concluded that with widespread exposure to magnetic fields, there might be a 15 to $25 \%$ increase in the rate of childhood leukemia. [21], carried out a pooled analysis of case-control studies to examine nighttime residential exposures of ELFEMF and risk of childhood leukemia. Data from four countries (Canada, Germany, UK and the US) were included in the investigation, covering 1,842 children diagnosed with leukemia and 3,099 controls. The obtained results deny the hypotheses that nighttime measures are more suitable. [22], presented a pooled analysis on primary data from studies on residential magnetic fields and childhood leukemia published after 2000. The main analysis focused on 24-hrs magnetic field measurements, and the results were presenting relation between magnetic fields and 
childhood leukemia. All the pooled and meta-analysis studies did not specify the common distance of the transmission lines from receiver i.e. children or adult. This commonly show the magnetic field density can be restrict up to $0.3-0.4 \mu \mathrm{T}$.

\section{Residential zone assessment}

[23], demonstrate their study in UK and Germany; the distance from power lines is a poor predictor of measured residential magnetic fields. On the basis of this study, they conclude that the measurements of residential magnetic field exposure misclassify the findings that rely on distance alone. [24], inspects potential of paternal occupational exposure and childhood leukemia in Great Britain. A total of 16764 cases of childhood leukemia were identified. One exposure group, paternal social contact, was associated with total childhood leukemia; this association remained significant when adjusted for social class. The results showed some support for a positive association between childhood leukemia risk and paternal occupation involving social contact. [25], estimated the ELF-EMF exposure distributions using studies recognized in the existing works. On the basis of that they conclude that according to the current state of the evidence, residential exposure to ELF-EMF may contribute to cases of leukemia in children, but this contribution is relatively small. Another exposure assessment by [26], in six buildings at the different distance of Ota, Nigeria was found to be above the safety limit by ICNIRP. So, the people residing close to power lines are more susceptible to health hazards.

The residential zone assessment studies mainly focus on location of the residents, medical database of leukemia cases, parental occupational contacts, development of buildings below power lines etc. but the other environmental interferences like conducting surface, high frequency source, family population can be change the radiation scenario in residential zone. Some remarkable efforts made by Nigerian researcher to explore the ill effects of low and high frequency EMF radiations.

\section{Case-control study}

[27], studies 399 leukemia cases and 399 controls selected for this assessment. Monitoring results of 24-hour bedroom magnetic field measurements and 48- hour personal EMF measurements were analyzed to identify the exposure methodology. The OR (Odds ratio) $=1.72$ compared with underground wiring, $95 \%$ confidence interval $0.54-5.45$. Their findings provide little support for an EMF exposure risk. The population-based study prepared by the United
Kingdom Childhood Cancer in 2000 on 6770 residents near high voltage power lines did not found any significant relationship with cancer. However, the duration exposure was not mentioned during this assessment [28]. [29], also suggested that distance and exposure index was not interlinked with acute lymphoblastic leukemia (ALL). However, magnetic field from home appliances may have relation with the both. [30], examine the causal nature and biological basis of ELF electro-magnetic fields on DNA damage response processes and childhood leukemia. This study spurn the mechanistic hypothesis that environmental ELF fields at relatively high levels might be causally connected with excess childhood leukemia. [31], did the largest study in this field in England and Wales, there epidemiological case-control study of 33000 children within an age of 0 to 14 years shows the distance of residence from power lines was associated with risk of childhood leukemia.

A Japanese case-control study in an area populated by $54 \%$ children, they analyze 915 case and control children within age group of 0 to 15 years. A weekly average magnetic field level was determined for the child's bedroom. The result provided by them shows an additional support that risk of childhood leukemia, particularly of ALL was associated with high magnetic field exposure [32]. Likewise [33], carried out a field study in Taipei City and Northern Taiwan to explore the exposure of ELF-MF among children at schools near high voltage transmission lines. The result obtained shows that there was an extensive range of exposures to ELF-EMF schools nearby HVTL, and children during school hours have a higher chance of leukemia. [34], also adopted the same methodology in Iran, the residence within $500 \mathrm{~m}$ from High-Voltage Power Lines. The author presented that residing within $500 \mathrm{~m}$ from power lines should be a factor in acute leukemia. [35], inspected the association amid magnetic field exposure and the existence of prognostic risk factors among 482 children identified with acute lymphoblastic leukemia. By using a personal 24-hour magnetic field meter measurements were obtained. There were no leanings seen between increasing exposure of magnetic field and the presence of adverse clinical and tumor-specific prognostic factors. In the same way[36], diagnosed a case-control study of childhood leukemia cases in between 1990 to 1995 in five Canadian provinces. They conclude that, although there is some evidence, it is dubious to explain entirely the relation of magnetic field exposure and childhood leukemia entirely. [37], evaluated the outcome of $60 \mathrm{~Hz}$ magnetic fields on acute lymphocytic leukemia, this case-control study 
involved all cases 162 and controls 565. 24-hour measurements in children rooms were taken. Overall results refute the association of magnetic fields and childhood leukemia.

Similarly in 2014, the case-control study of 53515 children from the national registry of childhood tumors 1962-2008. The distances of mother's address at child's birth to power lines at 132, 275, and 400 $\mathrm{kV}$ in England, Wales and Scotland [38]. [39], examined role of newly constructed power line onto the reported health issues. They investigated pre-tests and post-tests on the peoples who were residing near and far from the power lines. Based on their sex, age, educational level and occupational status observation the linear mixed model were fitted and concluded a positive relation between health problems and new power lines. Most of the case control studies end with non-consistent but significant effects on different cases and medical database. Many times these studies were segregated based on odd ratio and confidence interval. Some European researcher also tried develops the exposure model for childhood leukemia.

\section{Other effects on children and adults}

A survey based study on reproductive hazards of low frequency EMF was conducted by [40], their study includes 542 workers at Swedish power plants, questionnaire prepared and $89 \%$ workers were answer. Statistically a significant decreased in normal pregnancy were observed due to increased occurrence of congenital malformations, if father was a highvoltage switchyard worker. [41], conducted an epidemiological study to discover the relation between occupation and occurrence of brain tumor, using the data from death certificate of 951 adults in Maryland residents. The persons who worked in electric or electronic industry and utility company were found to experience a significantly higher risk of primary brain tumors. [42], accomplish a casecontrol study of the 157 children who died from neuroblastoma and 314 control who live births in Texas. They reported that children were at significantly high risk, whose father were electronic worker [43]. [44], carried out a mortality based casecontrol study of childhood brain tumor with respect to parent occupation, a comparative study of children who died due to brain tumor were compared with control children in Ohio. Their finding supports the hypothesis that occupation of parents was a significant aspect for childhood brain tumors. Another study by the same methodology was also done by Johnson and Spitz in Texas, and concluded a high risk for fathers who were electricians [45].
It is a common opinion among the experts [46, 47, 48] that results obtained related to reproductive problems like reproductive disturbance, risk of miscarriage and pregnancy problem shows increase in risk of reproductive disorders. The other biological effect linked with exposure to ELF EMF was reported in some studies such as, [49], piloted a telephone survey of people living next to a transmission line, and a control population casually picked from telephone directories. They found higher ratios of depression and suicide [50], among people living next to lines. [51], occupational exposure to low-frequency EMF was studied in 250 leukemia patients and 261 brain-tumor cases and compared with a control group of 1,121 from the mid-region of Sweden. At 1,015 altered workplaces exposure assessment were measured and agrees with the assumption that occupational EMF exposure is a hazard in the development of certain cancers.

[52], in one of the case control study the three different categories of workers from electric utility industries were selected to observe 29 types of cancer symptoms. The exposure and dose rate were change, they observed that the cumulative exposure effects of magnetic field more than $90 \%$ have elevated risk of brain cancer however no association were found with other categories of cancer. [53], accompanied a mortality study of 21,236 men working in utility companies in Denmark. The reason behind the death of worker was find out in between 1974-1993, and cause-specific death was analyzed. Their findings did not support the hypothesis of a link between occupational exposures to $50-\mathrm{Hz}$ EMF. The excess mortality from amyotrophic lateral sclerosis seems to be linked with electromagnetic fields exposure above average levels and may be due to repeated incidents with electric shocks. Similar studied were conducted on the children's and their group in different municipalities of Italy [54, 55], carried out a casecontrol study to find out residential exposure to magnetic fields and the development of childhood cancer in Colorado. 356 residents were identified and in-home electric and magnetic field measurements were taken under low and high power use condition. The finding shows neither magnetic field nor electric fields beneath high power were relating to cancer.

A meta-analysis based on 14 different studies of occupational exposure of ELF was carried out by Garcia et al. Based on available epidemiological evidences author acclaimed an association between occupational exposures [56]. A pooled analysis from 10 studies of exposure to extremely low frequency EMF and childhood brain tumors to evaluate the relation in comparison with exposure of $>0.1 \mu \mathrm{T}$ 
magnetic field. Their result indicates a positive relationship [57]. [58], exposed human neuroblastoma cell line to $2 \mathrm{mT}, 50 \mathrm{~Hz}$ magnetic field for 3 hours .They found that ELF-EMF alter cell morphology via changing protein expression. This interesting outcome opens new door for neurology.

\section{Showing the association i.e. "Fifteen years of study" on ELF-EMF \& CL}

In the above literature, certain important parameters those were complex to understand for electrical community during assessment are highlighted in this section. The distance from transmission lines, number of samples/cases, duration of exposure, frequency range and geographical location of assessment for magnetic field power density cannot be neglected as they play the vital role in environmental ELF-EMF assessment. As depicted in table no.1. These parameters are assessable and equally essential during the electromagnetic assessment of studies.

\begin{tabular}{|c|c|c|c|c|c|}
\hline Study & $\begin{array}{l}\text { No. of Sample } \\
\text { (cases/control } \\
\text { ) }\end{array}$ & $\begin{array}{l}\text { Distance } \\
(\mathrm{m})\end{array}$ & $\begin{array}{l}\text { Exposur } \\
\text { e Time } \\
\text { (Hr.) }\end{array}$ & Location & Short conclusion ${ }^{\text {(no. of citations) }}$ \\
\hline $\begin{array}{l}\text { McBride et } \\
\text { al., } 1999\end{array}$ & $399 / 399$ & NA & 48,24 & $\begin{array}{l}\text { In bedroom and } \\
\text { personal } \\
\text { monitoring }\end{array}$ & $\begin{array}{l}\text { Little support for relation } \mathrm{b} / \mathrm{w} \\
\text { ELF and CL. }\end{array}$ \\
\hline $\begin{array}{l}\text { Kleinerman et } \\
\text { al., } 1999\end{array}$ & $408 / 408$ & $<40 \mathrm{~m}$ & $>48$ & Children's home & $\begin{array}{l}\text { neither distance nor exposure } \\
\text { index was related to risk of } \\
\mathrm{ALL}^{(56)}\end{array}$ \\
\hline $\begin{array}{l}\text { Ahlbomet al., } \\
2000\end{array}$ & $3203 / 10338$ & NA & 24,48 & $\begin{array}{l}\text { Vicinity of } \\
\text { transmission line }\end{array}$ & $\begin{array}{l}\mathrm{EMF}<0.4 \mu \mathrm{T} \text { no effect, }>0.4 \mu \mathrm{T} \\
\text { relative risk of CL. }(704)\end{array}$ \\
\hline $\begin{array}{l}\text { Greenland et } \\
\text { al., } 2000\end{array}$ & 12 & $300-500$ & $\begin{array}{l}12,24 \\
48\end{array}$ & $\begin{array}{l}\text { In the vicinity of } \\
\text { HPTL }\end{array}$ & $\begin{array}{l}\text { positive relation between } \mathrm{H} \text {-field } \\
\text { and CL }{ }^{(499)}\end{array}$ \\
\hline $\begin{array}{l}\text { Draper et al., } \\
2005\end{array}$ & 33000 & $0-599$ & $>48$ & Near HPTL & High risk of $\mathrm{CL}^{(301)}$ \\
\hline $\begin{array}{l}\text { Kabuto et al., } \\
2006\end{array}$ & $312 / 603$ & NA & $>48$ & $\begin{array}{l}\text { In child's } \\
\text { bedrooms }\end{array}$ & 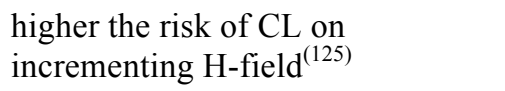 \\
\hline $\begin{array}{l}\text { Chung et al., } \\
2007\end{array}$ & $101 / 123$ & 100 & 24 & $\begin{array}{l}\text { Inside classes in } \\
\text { school and child's } \\
\text { bedroom }\end{array}$ & $\begin{array}{l}\text { Children face EMF }>0.4 \mu \mathrm{T} \text { during } \\
\text { school hours }^{(14)}\end{array}$ \\
\hline $\begin{array}{l}\text { Feizi and } \\
\text { Arabi, } 2007\end{array}$ & $60 / 59$ & $\begin{array}{l}63-880 \\
100-1100\end{array}$ & $>48$ & $\begin{array}{l}\text { at residence near } \\
\text { HPTL }\end{array}$ & $\begin{array}{l}\text { within } 500 \mathrm{~m} \text { the } \mathrm{H} \text { field }>0.45 \mu \mathrm{T} \text {, } \\
\text { may increase risk of } \mathrm{CL}^{(38)}\end{array}$ \\
\hline $\begin{array}{l}\text { UKCCS, } \\
2007\end{array}$ & $3380 / 3390$ & $40-600$ & $>48$ & $\begin{array}{l}\text { Near children's } \\
\text { residence }\end{array}$ & $\begin{array}{l}\text { Children living }<200 \mathrm{~m} \text { have great } \\
\text { risk of CL than beyond } 600 \mathrm{~m}^{(191)}\end{array}$ \\
\hline $\begin{array}{l}\text { Foliart et al., } \\
2007\end{array}$ & 412 & NA & 24 & Childs bedroom & $\begin{array}{l}\text { No link with the presence of } \\
\text { defects in leukemic blast cells }\end{array}$ \\
\hline $\begin{array}{l}\text { Schuz et al., } \\
2007\end{array}$ & $1842 / 3099$ & NA & 24,48 & Childs bedroom & no strong association ${ }^{(27)}$ \\
\hline $\begin{array}{l}\text { Martha et al., } \\
2008\end{array}$ & $638 / 620$ & $0-46$ & 24 & Child bedroom & $\begin{array}{l}\text { medium risk of CL due to high } \\
\text { H-field of transmission lines }\end{array}$ \\
\hline $\begin{array}{l}\text { Mezei et al., } \\
2008\end{array}$ & $399 / 399$ & NA & 48,24 & Near HPTL & $\begin{array}{l}\text { Association of H-field and CL is } \\
\text { doubtful to explain. }\end{array}$ \\
\hline
\end{tabular}




\begin{tabular}{|c|c|c|c|c|c|}
\hline $\begin{array}{l}\text { Maslanyj et } \\
\text { al., } 2009\end{array}$ & 1835 & $0-500$ & $24 \& 48$ & $\begin{array}{l}\text { child bedroom and } \\
\text { spot check }\end{array}$ & $\begin{array}{l}\text { Misclassification render the } \\
\text { findings from studies that rely on } \\
\text { distance alone uninterpretable }{ }^{(31)}\end{array}$ \\
\hline $\begin{array}{l}\text { Kheifets et } \\
\text { al., } 2010\end{array}$ & $10865 / 12853$ & NA & 24 & Pooled analysis & $\begin{array}{l}\text { support the previous studies on } \\
\text { positive relation of } \mathrm{H} \text {-field and } \\
\mathrm{CL}^{(97)}\end{array}$ \\
\hline $\begin{array}{l}\text { Filho et al., } \\
2011\end{array}$ & $162 / 565$ & $50-600$ & 24 & $\begin{array}{l}\text { Inside and outside } \\
\text { the houses }\end{array}$ & $\begin{array}{l}\text { No strong relation between } \mathrm{MF} \\
\text { and CL conclusion }^{(14)}\end{array}$ \\
\hline $\begin{array}{l}\text { Keegan et al., } \\
2012\end{array}$ & $17793 / 16764$ & NA & 24 & Near power lines & $\begin{array}{l}\text { Positive association between CL } \\
\text { and paternal occupation involving } \\
\text { social contact }^{(12)}\end{array}$ \\
\hline $\begin{array}{l}\text { Grellier et al., } \\
2013\end{array}$ & $14132 / 9610$ & NA & $>48$ & Inside homes & Poor relation with $\mathrm{CL}^{(25)}$ \\
\hline $\begin{array}{l}\text { Bunch et al., } \\
2014\end{array}$ & 53515 & $0-600$ & $>48$ & Child's residence & $\begin{array}{l}\text { effect size was half of the effect } \\
\text { previously reported }^{(20)}\end{array}$ \\
\hline $\begin{array}{l}\text { Adekunle et } \\
\text { al., } 2015\end{array}$ & 10 & $2-12$ & 12 & $\begin{array}{l}\text { The building near } \\
\text { HPTL }\end{array}$ & Increase risk of $\mathrm{CL}^{(0)}$ \\
\hline
\end{tabular}

*ALL (acute lymphoblastic leukemia), *HPTL (high power transmission line), *CL (childhood leukemia), *NA (not applicable/ reported).

Table 1: Showing the association of extremely low-frequency electromagnetic field and childhood leukemia from different studies.

Although most of the studies have been carried out in the western part of world and other developed countries, population density of this region is very less compared to eastern countries. Thus, some studies have not mentioned the number of samples i.e. cases and control selected during this analysis. The secondary data representation in some analysis is clearly mentioned and estimated trends of magnetic fields as per distance hence it is difficult to neglect no. of samples in their pooled analysis[18][22] [24] [38].

In case control studies wide range of cases and controls were selected in addition of all samples/cases are considered during collection of the data. In major case control studies equal and unequal number of controls was selected. However, their age group, body mass index, immunity against EMF is not clearly revealed. Important constraint of the above table is the number of samples. Unfortunately no uniformity was observed during sample count for analysis. Hence the statistical analysis of publication year Vs samples quantity in Figure 1 shows exponential year wise sample selection in all studies. The sample selected during 1999-2006 was less compared to 2007-2015. This may be due to increase in of long term exposure studies and statistics for assessment of epidemiological studies. However it is very difficult to extract all the information in terms of exposure statistic due to mixed sample selection. The sample selection was user dependent hence that it difficult to observe the repeatability. 


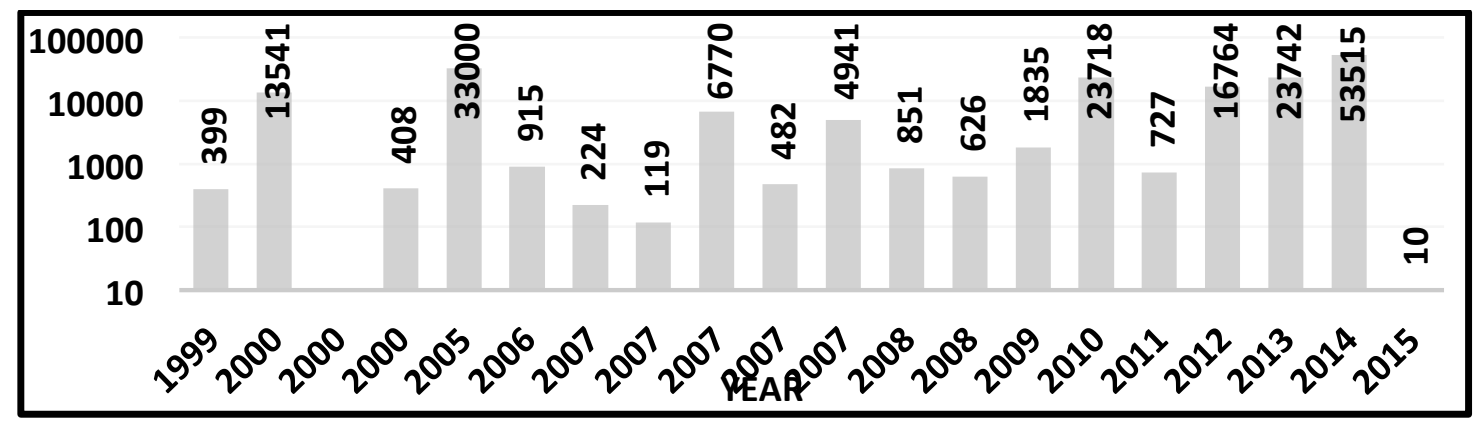

Fig.1. Year Vs No. of sample

Duration of exposure is another critical parameter for biological exposure assessment. The duration of dose and exposure relationship still not yet cleared in major case control studies of ELF-EMF. Time interval between doses, frequency of ELF-ELM was not commonly selected. Hence, it is observed that the duration of exposure is varied from zero to $24,48, \geq$ 48 Hrs. No specific criteria were adapted for exposure duration. The Figure 2 depicts year wise exposure dose trend. The limited exposure (24 Hrs \& 48Hrs) was not supporting the CL and ELF-EMF association white long-term and continuous exposure. The CL shows association with ELF-EMF observed in all $\geq$ 48Hrs exposure studies. This shows importance of long-term duration studies in order to identify the fair link between EMF- ELF and childhood leukemia.

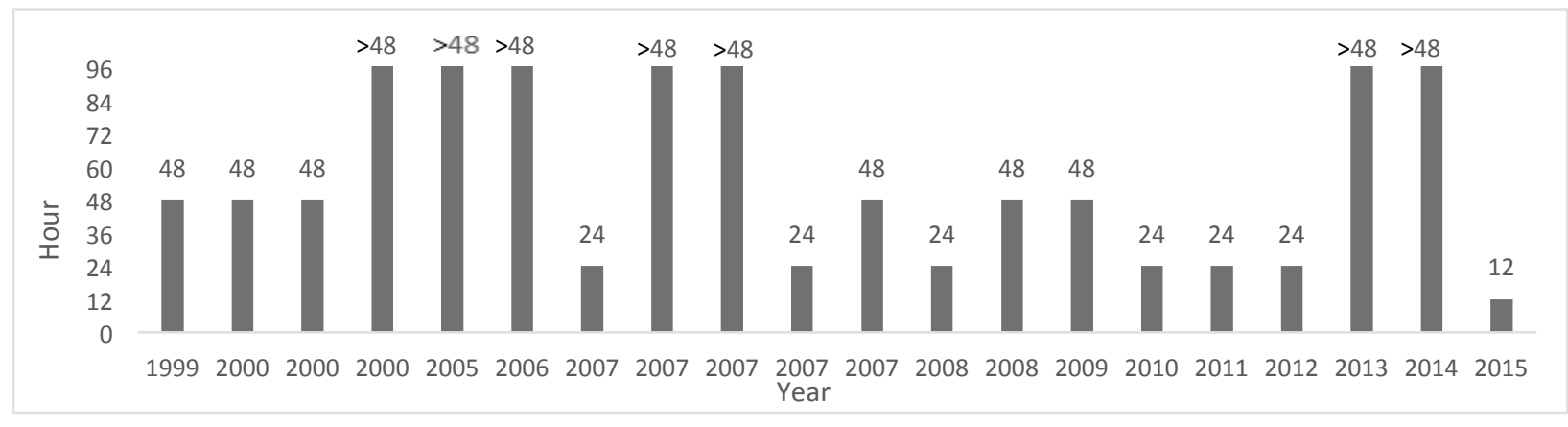

Fig.2. Year Vs exposure dose (Hr.)

The objective of this analysis was to show year wise trending of ELF-EMF research in association with CL.

The complex biological exposure assessment outcome from selected 20 studies had been divided on the basis of general fair relation, poor relation and no relation with $\mathrm{CL}$. In the next step, among total the small/non-clear association in all results was consider under "No comment" category while complementary conclusions were included in the "No support" category as shown in figure 3. Total no. of cases studied were 20 while 5 had declined any primary or secondary correlation between ELF-EMF and CL. with childhood leukemia. Hence, the results under yes category are only representing "support for association" to this correlation study. However it is very difficult to confirm statistical exposure due to lack of biological exposure database from authors. This effort made to categories case control studies outcomes.

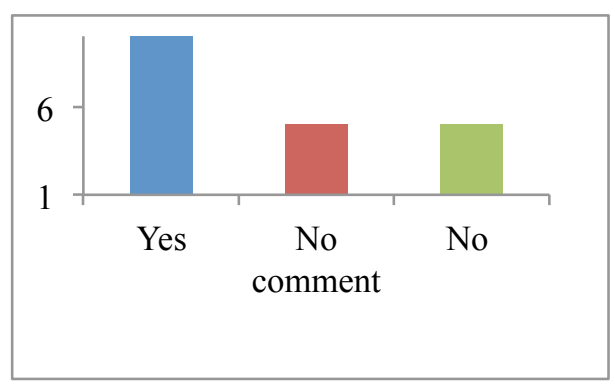

Fig.3. Association of ELF-EMF with CL

Major studies were carried out near transmission line, homes, schools hence transmission lines were the main source of ELF in the frequency of 50 to $60 \mathrm{~Hz}$. Distance taken during calculation of magnetic field density was varied from $0-600 \mathrm{~m}$ and some studies have not mentioned the distance from source. Hence, 
it is very difficult to conclude common relation or equation for further research.

\section{Conclusion \& Recommendations}

The screening of the literature was collected and provided very limited number of electromagnetic parameters endpoints from the total database. All important but unknowingly neglected parameters in all studies were statistically analyzed to obtain the correlation between number of sample, distance from source and duration of exposure. But no co-relation with the type of dose and duration of exposure found in all studies. No clear relation observed between specific source and childhood leukemia. Major studies were conducted in the western and northern part of the world however very little evidence of study in the highly populated country like India. It is very difficult to conclude statistical analysis or model from the selected study. However among total studies major studies were positively involved in association between EMF and CL. The conditions found in laboratory cannot replace the real- time outdoor study. Hence the results obtained in this human science scale may change due to inadequate expertise in biological case control statistic. No common distance from source was selected but majority of findings were weakly associated between ELF-EMF and childhood leukemia if magnetic field exposure level $\geq 0.3 / 0.4 \mu \mathrm{T}$.

Development of biomarkers, biological exposure modeling and mapping and impact assessment of high population density due to ELF-EMF are the neglected areas in this field. The wide gap between biological exposure modeling and electrostatic field modeling can be observed in during data analysis. Determination of the specific absorption rate (SAR), body mass index (BMR), internal electric and magnetic fields are very complicated but equally important to interlink the biological studies and EMF monitoring experiments. Hence, this analysis fills the gap between complex biological case control statistics and electrostatic analysis. The increase risk of CL and other epidemiological diseases in dense populated region is among major challenges for $21^{\text {st }}$ century. Major studies suggested the continuous monitoring of magnetic and electric filed density near power lines. Continuous exposure monitoring similar to air quality, noise etc. is very important due to increase in the electro-smog and worldwide population. It is necessary to have common standard guideline at worldwide level to avoid confusion during assessment. More outdoor ELF studies are recommended to identify the long-term effects on ELF on human beings so that we can protect developing and high population density like India.
Public awareness about electro-smog, heterogeneous research activities can only give the better solution for future generation.

\section{Acknowledgements}

The authors like their thank to Council of Scientific and Industrial Research Institute, New Delhi for the grant in aid support to CSIR-NEERI, Nagpur. Authors report no conflict of interest and alone responsible for content and script of the paper.

\section{References}

1. Genuis SJ. Fielding a current idea: exploring the public health impact of electromagnetic radiation. Public Health 122(2):113-124, 2008.

2. Calvente I, Fernandez MF, Villalba J, Olea N, Nunez MI. Exposure to electromagnetic fields (non-ionizing radiation) and its relationship with childhood leukemia: A systematic review. Science of the Total Environment 408:30623069, 2010.

3. IARC and Working Group on the Evaluation of Carcinogenic Risks to Humans. Non ionizing radiation, Part 1: static and extremely lowfrequency (ELF) electric and magnetic fields. Lyon: IARC Press; 2002.

4. National Institute of Environmental Health Sciences (NIEHS). Working group report: Assessment of health effects from exposure to power-line frequency electric and magnetic fields. NIH Publication No. 98-3981, 1998.

5. International Telecommunication Union. 2015. Nomenclature of the frequency and wavelength bands used in telecommunications. Recommendation ITU-R V.431-8, 2015.

6. Environmental Health Criteria 238. Extremely low-frequency field published under the joint sponsorship of the International Labour Organization, the International Commission on Non-Ionizing Radiation Protection, and the World Health Organization, 2007.

7. Simko Myrtill and Mattsson Mats-Olof. Extremely Low Frequency Electromagnetic Fields as Effectors of Cellular Responses In Vitro: Possible Immune Cell Activation. Journal of Cellular Biochemistry 93:83-92, 2004.

8. Kulkarni Girish, Gandhare WZ. Living bodies exposed to natural and artificial extremely low 
frequency electromagnetic fields. IJEECS. Volume 3, Issue 2, 2014.

9. IEEE Recommended Practice for Measurements and Computations of Electric, Magnetic, and Electromagnetic Fields with Respect to Human Exposure to Such Fields, $0 \mathrm{~Hz}$ to $100 \mathrm{kHz}$. IEEE - The Institute of Electrical and Electronics Engineers. (IEEE Std. C95.3.1-2010).

10. ICNIRP. Guidelines for limiting exposure to time-varying electric and magnetic fields (up to 1 Hz-100 kHz). Health Phys 99(6):818-836, 2010.

11. WHO-portal available from http://www.who.int/pehemf/about/WhatisEMF/e $\mathrm{n} /$.

12. Bhatia S, Ross J, Greaves M, Robison L. Chapter 3: Epidemiology and etiology. In: Pui C-H, editor. Childhood leukemias. New York: Cambridge University Press. pp 38-49, 1999.

13. Ager EA, Schuman LM, Wallace HM, Rosenfield AB, Gullen WH. An epidemiological study of childhood leukemia. J Chronic Dis 18:113-32, 1965.

14. Wertheimer N, Leeper E. Electrical wiring configurations and childhood cancer. Am J Epidemiol 109:273-84, 1979.

15. Linet MS, Elizabeth EH, Kleinerman RA, Robison LL, Kaune WT, Friedman DR, Severson RK, Haines CM, Hartsock CT, Niwa S, Wacholder S, Tarone RE. Residential exposure to magnetic fields and acute lymphoblastic leukemia in children. The New England Journal of Medicine. 337(1):1-7, 1997.

16. Ramon R, Ballester F, Rebagliato M, Ribas N, Torrent M, Fernandez M. The environment and childhood research network ("INMA" network): study protocol. Rev Esp Salud Publica 79(2):203-20, 2005.

17. Theriault Gilles, Chung-Yi Li. Risks of leukemia among residents close to high voltage transmission electric lines. Occupational and Environmental Medicine 54:625-628, 1997.

18. Greenland S, Sheppard AR, Kaune WT, Poole C, Kelsh MA. A pooled analysis of magnetic fields, wire codes, and childhood leukemia. Childhood Leukemia-EMF Study Group. Epidemiology 11:624-34, 2000.

19. Ahlbom A, Day N, Feychting M, Roman E, Skinner J, Dockerty J. A pooled analysis of magnetic fields and childhood leukemia. $\mathrm{Br} \mathrm{J}$ Cancer 83:692-8, 2000.

20. Wartenberg D. The potential impact of bias in studies of residential exposure to magnetic fields and childhood leukemia. Bioelectromagnetics 5:S32-47, 2001.

21. Schuz J. Implications from epidemiologic studies on magnetic fields and the risk of childhood leukemia on protection guidelines. Health Phys 92(6):642-648, 2007.

22. Kheifets L, Ahlbom A, Crespi CM, Draper G, Hagihara J, Lowenthal RM, Mezei G, Oksuzyan S, Schüz J, Swanson J, Tittarelli A, Vinceti M, Wunsch Filho V. 2010. Pooled analysis of recent studies on magnetic fields and childhood leukemia. British Journal of Cancer 103:11281135. 2010.

23. Maslanyj M, Simpson J, Roman E, Schuz J. Power Frequency Magnetic Fields and Risk of Childhood Leukemia: Misclassification of Exposure from the Use of the 'Distance From Power Line' Exposure Surrogate. Bioelectromagnetics 30:183-188, 2009.

24. Keegan TJ, Bunch KJ, Vincent TJ, King JC, O'Neill KA, Kendall GM, MacCarthy A, Fear NT, Murphy MF. Case-control study of paternal occupation and childhood leukemia in Great Britain, 1962-2006. British Journal of Cancer 107:1652-1659, 2012.

25. Grellier J, Ravazzani P, Cardis E. Potential health impacts of residential exposures to extremely low frequency magnetic fields in Europe. Environment International 62:55-63, 2014.

26. Adekunle A, Ibe KE, Kpanaki ME, Umanah II, Nwafor CO, Essang N. Evaluating the Effects of Radiation from Cell Towers and High Tension Power Lines on Inhabitants of Buildings in Ota, Ogun State. Communications in Applied Sciences. 3(1):1-21, 2015.

27. McBride ML, Gallagher RP, Theriault G, Armstrong BG, Tamaro S, Spinelli JJ, Deadman JE, Fincham S, Robson D, Choi W. Powerfrequency electric and magnetic fields and risk of childhood leukemia in Canada. Am J Epidemiol. 149(9):831-42, 1999.

28. UKCCS (UK Childhood Cancer Study Investigators). Exposure to power-frequency magnetic fields and the risk of childhood cancer. Lancet 354:1925-31, 1999. 
29. Kleinerman RA, Kaune WT, Hatch EE, Wacholder S, Linet MS, Robison LL, Niwa S, Tarone RE. Are Children Living Near HighVoltage Power Lines at Increased Risk of Acute Lymphoblastic Leukemia? American Journal of Epidemiology. 151(5):512-5, 2000.

30. Hone P, Edwards A, Halls J, Cox R, Lloyd D. Possible associations between ELF electromagnetic fields, DNA damage response processes and childhood leukemia. British Journal of Cancer 88(12):1939 - 1941, 2003.

31. Draper G, Vincent T, Kroll ME, Swanson J. Childhood cancer in relation to distance from high voltage power lines in England and Wales: a case-control study. Br Med J 330:1290-4, 2005 .

32. Kabuto M, Nitta H, Yamamoto S, Yamaguchi N, Akiba S, Honda Y, Hagihara J, Isaka K, Saito T, Ojima $\mathrm{T}$, Nakamura $\mathrm{Y}$, Mizoue $\mathrm{T}$, Ito $\mathrm{S}$, Eboshida A, Yamazaki S, Sokejima S, Kurokawa Y, Kubo O. 2006. Childhood leukemia and magnetic fields in Japan: a casecontrol study of childhood leukemia and residential power-frequency magnetic fields in Japan. Int J Cancer 119:643-50, 2006.

33. Li CY, Sung FC, Chen FL, Lee PC, Silva M, Mezei G. Extremely-low-frequency magnetic field exposure of children at schools near high voltage transmission lines. Science of the Total Environment 376:151-159, 2007.

34. Feizi AA, Arabi MA. Acute childhood leukemias and exposure to magnetic fields generated by high voltage overhead power lines: a risk factor in Iran. Asian Pac J Cancer Prev 8(1):69-72, 2007.

35. Foliart DE, Mezei G, Iriye R, Silva JM, Ebi KL, Kheifets L, Link MP, Kavet R, Pollock BH. Magnetic Field Exposure and Prognostic Factors in Childhood Leukemia. Bioelectromagnetics 28(1):69-71, 2007.

36. Mezei G, Spinelli JJ, Wong P, Borugian M, McBride ML. Assessment of Selection Bias in the Canadian Case-Control Study of Residential Magnetic Field Exposure and Childhood Leukemia. American Journal of Epidemiology 167(12):1504-10, 2008.

37. Victor Wunsch-Filho, Daniele M. Pelissari, Flavio E. Barbieri, Leonel Sant Anna, Claudia T. de Oliveira, Juliana F. de Mata, Luiz G. Tone, Maria Lucia de M. Lee, Maria Lydia M. de
Andrea, Paula Bruniera, Sidnei Epelman, Vicente Odone Filho, Leeka Kheifets. Exposure to magnetic fields and childhood acute lymphocytic leukemia in Sao Paulo, Brazil. Cancer Epidemiology 35 534-539, 2011.

38. Bunch KJ, Keegan TJ, Swanson J, Vincent TJ and Murphy MFG. Residential distance at birth from overhead high-voltage power lines: childhood cancer risk in Britain 1962-2008. British Journal of Cancer 110:1402-1408, 2014.

39. Porsius JT, Claassen L, Smid T, Woudenberg F, Petrie KJ, Timmermans DR. Symptom reporting after the introduction of a new high-voltage power line: A prospective field study. Environmental Research 138:112-117, 2015.

40. Nordstrom S, Birke E and Gustavsson L. Reproductive Hazards among Workers at High Voltage Substations. Bioelectromagnetics 4:91$101,1983$.

41. Lin RS, Dischinger PC, Conde J and Farrell KP. Occupational exposure to electromagnetic fields and the occurrence of brain tumors. Journal of Occupational Medicine 27:413-419, 1985.

42. Spitz MR and Johnson CC. Neuroblastoma and paternal occupation, a case-control analysis. American Journal of Epidemiology 121:924-929, 1985.

43. Deapen DM and Henderson BE. A case-control study of amyotrophic lateral sclerosis. American Journal of Epidemiology 123:790- 798, 1986.

44. Wilkins JR, III and Koutras RA. Paternal occupation and brain cancer in offspring: A mortality-based case-control study. American Journal of Industrial Medicine 14:299-318, 1988.

45. Johnson CC and Spitz M. Childhood nervous system tumours: An assessment of risk associated with paternal occupations involving use, repair or manufacture of electrical and electronic equipment. International Journal of Epidemiology 18:756-762, 1989.

46. Goldhaber MK, Polen MR and Hiatt RA. The risk of miscarriage and birth defects among women who use visual display terminals during pregnancy. American Journal of Industrial Medicine 13:695-706, 1988.

47. Li DK, Odouli R, Wi S, Janevic T, Golditch I, Bracken TD, Senior R, Rankin R, Iriye R. A population-based prospective cohort study of 
personal exposure to magnetic fields during pregnancy and the risk of miscarriage. Epidemiology 13(1):9-20, 2002.

48. Tornqvist, S. Paternal work in the power industry: Effects on children at delivery. Journal of Occupational and Environmental Medicine 40:111- 117, 1998.

49. Poole C, Kavet R, Funch DP, Donelan K, Charry JM, Dreyer NA. Depressive symptoms and headaches in relation to proximity of residence to an alternating-current transmission line right-ofway. American Journal of Epidemiology 137(3):318-330, 1993.

50. Reichmanis, M, Perry FS, Marino AA and Becker RO. Relation between suicide and the electromagnetic field of overhead power lines. Physiology, Chemistry and Physic 11:395-403, 1979.

51. Floederus, B, Persson T, Stenlund C, Wennberg W, Ost A, and Knave B.. Occupational exposure to electromagnetic fields in relation to leukemia and brain tumors: a case-control study in Sweden. Cancer Causes Control 4:465-476, 1993.

52. Theriault G, Goldber M, Miller AB, Armstrong B, Guenel P, Deadman J, Imbernon E, To T, Chevalier A, Cyr D and Wall C. Cancer risks associated with occupational exposure to magnetic fields among electric utility workers in Ontario and Quebec, Canada, and France: 19701989. American Journal of Epidemiology 139:550-572, 1994.

53. Johansen $\mathrm{C}$ and Olsen J. Mortality from amyotrophic lateral sclerosis, other chronic disorders, and electric shocks among utility workers. American Journal of Epidemiology 148:362-368, 1998.

54. Malagoli C, Fabbi S, Teggi S, Calzari M, Poli M, Ballotti E, Notari B, Bruni M, Palazzi G, Paolucci P, Vinceti M. Risk of hematological malignancies associated with magnetic fields exposure from power lines: a case-control study in two municipalities of northern Italy. Malagoli et al. Environmental Health 30:9-16, 2010.

55. Savitz DA, Jianhua C. Parental Occupation and Childhood Cancer: Review of Epidemiologic Studies. Environmental Health Perspectives 88:325-337, 1990.

56. Garcia AM, Sisternas A, Hoyos SP. Occupational exposure to extremely low frequency electric and magnetic fields and Alzheimer disease: a meta-analysis. Int. J. Epidemiol 37(2):329-340, 2008.

57. L Kheifets, A Ahlbom, CM Crespi, M Feychting, C Johansen, J Monroe, MF Murphy, S Oksuzyan, S Preston-Martin, E Roman, T Saito, D Savitz, J Schüz, J Simpson, J Swanson, T Tynes, P Verkasalo, G Mezei, A Pooled Analysis of Extremely Low-Frequency Magnetic Fields and Childhood Brain Tumors, American Journal of Epidemiology 172(7):752-761, 2010.

58. H. Hasanzadeh, M. Rezaie-Tavirani, S.S. Seyyedi, H. Zali, S Heydari Keshel, M Jadidi, A Abedelahi, Effect of ELF-EMF Exposure on Human Neuroblastoma Cell Line: a Proteomics Analysis, Iran J Cancer Prev 7(1):22-27, 2014. 